\title{
Efforts in Improving The Quality of Education Through Educator's Profesionalism
}

\author{
Rini Rahman ${ }^{1}$, Dinovia Fannil Kher ${ }^{2}$, Murniyeti ${ }^{3}$, Yati Aisya Rani ${ }^{4}$, Muhamad Rezi ${ }^{5}$ \\ \{ rinirahman@fis.unp.ac.id ${ }^{1}$, dinovia.rezi@fbs.unp.ac.id ${ }^{2}$, murniyetti@fis.unp.ac.id ${ }^{3}$, \\ yati_aisya@fbs.unp.ac.id ${ }^{4}$, rezineddin@gmail.com ${ }^{5}$ \} \\ Faculty of Social Sciences, Universitas Negeri Padang, Indonesia ${ }^{1,3}$ \\ Faculty of Languages and Arts, Universitas Negeri Padang, Indonesia ${ }^{2,4}$ \\ Faculty of Ushuluddin Adab \& Dakwah Institut Agama Islam Negeri (IAIN) Bukittinggi, Indonesia ${ }^{5}$
}

\begin{abstract}
It has been obvious that the quality of many schools in Indonesia is below the global standard of education, specifically that of the primary and secondary schools. Many efforts have been carried out in order to escalate the quality of national education. However, the various education quality indicators in Indonesia present data that confirm Indonesia national education is below the expectation. One of the possible causes of this problem relates to the educators' professionalism. Using, a library-based research design, this article attempts to analyze efforts to escalate the quality of education by concerning more to the educators' professionalism improvement. Educators are the major component in a system of education. They are the center of transformation, internalization, and externalization of education values.
\end{abstract}

Keywords. Education, Quality, Professionalism, Educators.

\section{Introduction}

The quality of education has always been one of the major education issues in Indonesia. Various efforts have been conducted in order to improve the quality of education; developing curriculum and improving education facilities, and management quality at schools. However, some education quality indicators show that the significant improvements have not yet been achieved.

One of the problems lies in the teachers' professionalism where many teachers are found to be less competent in doing their role as teachers. Teacher's professionalism may be the main problem because ensuring that every school is representative, occupied with sophisticated facilities do not warrant that the goal of education can be achieved if the quality of the teachers is not improved.[1]

Among the components in education, according to Abuddin Nata,[2] teachers are the most important component. In line with this opinion, Saifullah, et.al also state that teachers are responsible for the improvement of education; students' competence.[3]

Educators or teachers are the main components in a system of education. Teachers are responsible to transform, internalize and externalize the moral and values of education. There will be no education without teachers. Therefore, a study about teachers, in terms of actual and conceptual has always been important to discuss. 


\section{Discussion}

The education constitution no 47 the year 2008 states new paradigms of education in Indonesia. It covers the vision and mission of the national curriculum, the teaching and learning process, and other educational aspects. The paradigms are meant to improve the quality of education. Therefore, educators and stakeholders are responsible to run the system as how it should be.[4]

\subsection{The Quality of Education}

Quality means to grade, class or level. Quality is the English language.[5] In Arabic, quality is translated as juudah.

Etymologically, quality means an improvement to a better condition. Quality may also mean how high or how low is something. In term of education, education quality means the implementation of education in an institution, and to what grade or level that institution has reached its goals.[6]

According to Supranta, quality is a something that a server needs to do properly.[7]

As how it has been explained by Guets and Davis in Tjiptono's book, that quality is a dynamic condition that relates to products, services, human, process, and environment that meet the expectations.

In the education context, the quality refers to the process and the outcome of the education. Process in education refers to any inputs such as teaching materials that cover the cognitive, affective and psychomotor aspect, methods that are used by teachers based on their capability, schools facilities, and administrative support.

School management serves to synchronize the various inputs and synergizes all components of the teaching and learning process; facilities inside and outside the class, curricular and extracurricular activities and academic and non-academic environment.

Moreover, the quality of education is the ability of the education system; in terms of management and process, to maximize the values and input factors in order to achieve the highest improvement.

A good education produces graduates who are skillful to learn and study, to create a better condition for the society, to be the agents of change that empower the education sources optimally through representative learnings.

It is possible to say the quality of education is the capability of education institutions to empower the learning sources in order to achieve the goals of education. A good education produces qualified graduates, not only achieving academic goals but also non-academics. The graduates are the agents of change that are well-prepared to be ready to cope with any upcoming situations,

Referring to the government regulation No 19 the year 2005 about the national standard of Indonesian Education, there are 8 indicators to be concerned:

a) Content, it refers to the materials, level of competency which is reflected in the graduates' competency criteria, and syllabuses.

b) The process, it relates to the learning process conducted to achieve the standard competency.

c) Graduates standard competency; refers to the qualifications of the graduates covering attitude, knowledge, and skills.

d) Teachers; teachers should be qualified, in terms of physical and education. 
e) Facilities; this covers the learning facilities such as classrooms, gym, rooms for worshiping, library, laboratory, workshops, and other facilities to support the use of information and technology.

f) Management; refers to the plan, implementation, and evaluation the educational activities.

g) Financing; manages the budget to run the education within a year.

h) Evaluation; relates to the mechanism, procedure, an instrument used to evaluate students' learning outcome.

The national standard of education functions as guidelines to plan, implement, and monitor the education in order to achieve the goals of education (subsection 4). It also functions to ensure the quality of education in order to enrich the lives of the nation and form dignified civilization (subsection 4). A good education meets the standard of National Education as stated in the government regulation no 19 the year 2005 .

\subsection{Professional Teacher}

Many education experts agree the improvement of education lies on the availability of the teachers.[8]

What does professional mean? There are criteria of being professional:

1) Knowledgeable. One must have the knowledge to be a teacher.

2) Work full time. A teacher should not have any part-time jobs.

3) The job is for a living. A teacher works for a living. The teacher does not need other jobs to support his/her life.

A qualified and professional teacher must have the academic qualification, competency, certificates, and physically and mentally healthy. The competency covers pedagogical, personality, social and professional competence. A teacher may have these competencies by taking teacher's education program managed by a university that offers an accredited teacher's education program. This policy is taken since managing the quality of teachers is not easy. As stated in the government regulation no 74 the year 2008 about teachers, competency is a set of knowledge, skills, and attitude, mastered and actualized by teachers in doing their professional roles.

The competency is holistic, obtained through professional education. The pedagogical competence includes a) knowledge about the field; b) knowledge about the students, curriculum, syllabuses, and lesson plans; c) implementing educative and dialogic education; using technology; d) evaluating the learning outcomes, and e) encouraging students to actualize their potentials.

The personality competence covers a) religious, b) noble character, c)wise, d) democratist, e) steady, f) authoritative, g) stable, h) mature, i) honest, j) role model for students and society, 1) objective evaluation.

The social competence covers a) the ability to communicate spoken and written, b) the ability to use technology communication and information functionally, c) the ability to interact positively with the students, d) the ability to socialize with the society, and e) and togetherness. The professional competence refers to teachers' ability to master their own field of study; a) the materials, and the subjects and b) the concept and the methods related to their field, the technology, and art to support their teaching. 
Abudin Nata in 2001 states characteristics of a professional teacher.[2] They are:

1) Besides being knowledgeable about what they teach, teachers need to have the skills to perform their knowledge. This is to ensure that the teaching and learning process can be done effectively and efficiently.

2) A professional teacher should have modern mental such as: have a vision, punctual, discipline, creative, innovative, dynamic, confident, open-minded.

3) A professional teacher is a religious person, noble and not affected by any secularists' belief. Being a professional teacher fulfills certain requirements. A professional teacher should be knowledgeable, and skillful. To be professional, a teacher should fulfill minimum qualification, certification and profession ethics. According to Oemar Hamalik, $[12\}$ there are 8 requirements for a professional teacher; 1) Having a talent as a teacher; 2) Having a skill a teacher; 3) Having well- integrated competencies; 4) Mentally health; 5) Physically health; 6) Experienced; 7) Uphold the Pancasila and; 8) A good civil.[9]

Based on research about professional qualification in education, a teacher has to be all-out doing his/her roles. A teacher should always have time to work, have integrity toward his job. A lecturer, for instance, should be at the campus from 8.00 am to $8.00 \mathrm{pm}$ so that whenever the students need him/her, they can easily find him/her. The integrity can also be seen from the renewals of the curriculum done by teachers or lecturers.

\section{Al-Quran and Teachers' Profesionalism}

Indeed, Allah commands you to render trusts to whom they are due and when you judge between people to judge with justice. Excellent is that which Allah instructs you. Indeed, Allah is ever Hearing and Seeing (An-Nisa' 58).

Based on the surah, there are some explanations related to professionalism. First, a professional is a trustworthy person. A teacher should not lose her vision and transcendentalist spirit; a belief that educating is a responsibility. Second, a professional teacher in the Islamic perspective is a skillful person. If the teacher is not skillful then it gives effects that last long. Therefore, a monitor is needed, such as institution monitors, parents, and the school committee.

Thirds, a professional teacher is an objective person. She/he serves and treats people like the way they should be treated. She/he evaluates the objects, not affected by some other issues attached to the object; such as appearance or wealthy.

\section{Efforts To Improve Teacher' Profesionalism}

Efforts to improve the quality of education through teachers' professionalism is a part of education reformation. The reformation is done by improving teachers' professionalism. A teacher is an important profession. It is the dominant part of the system of education. The quality of education relies on the quality of its teachers. One of the efforts done by the government in order to improve the quality of teachers is by issuing the regulation no 14 the year 2005 about teachers and lecturers. This regulation describes how the government tries to develop the profession by stating national standards of education and laws that protect it. Referring to some literature reviews, there are efforts that can be done in order to improve the quality of teachers. They are; 


\subsection{Teachers Are The Graduates of A Teaching Program.}

A teacher should be a graduate of a teaching program. For example, a primary school teacher should be a graduate of elementary school teacher program at an accredited university.

\subsection{Teachers' Professional Education}

As how the regulation no 20 the year 2003 about the National Education System, teachers' professional education is reflected on PPG. Therefore, the government does not only change the LPTK into PPG, yet some substantial changes have to be adjusted. In the regulation no 14 the year 2005 about teachers and lectures, in section 2, subsection 1, it is stated that teachers have a role as a professional on different levels; primary, high and higher education. On section 2, subsection 2, it is stated that teachers as a profession proven through a teaching certificate. In government regulation no 74 the year 2008, it is stated that teachers may obtain the certificate through three ways; teachers' professional education program, competency test, portfolio. The quality improvement is done to both teachers and teachers-to-be. In order to improve the teachers-to-be professionalism, the government develops a program called PPG. The students of PPG is the graduates of S1/D4 education and non- education program. This program is also meant for teachers who have not yet obtained the teaching certificate.

In order to have PPG as a program to help improve teachers' quality, the government should concern: 1) the requirements of the students and 2) the curriculum and learning model. The students should be the graduates from pure science and the learning model is based on teachers' competency. The program is formerly meant to improve the teaching quality. Therefore, the program should also focus on improving teachers' work motivation, to be more planned, directed, and continued. However, quite often, the implementation is focused more on the certification test.

In fact, the regulation no 11 states that in order to have teacher certificate, the qualification is S1 and teachers' professional education program. The certification test is mostly done by referring to portfolio evaluation, even without having to have the S1 qualification. The certification program should not be untied from the professional education program, and it is not meant a way to provide a raise. The raise given should be an incentive that motivates teachers to study. If the government means to improve teachers' welfare, then another regulation should be made. PPG should help the graduates to pass; curriculum designs; learning materials development; evaluation construction; learning media preparation; and class instructive designs. However, as stated by Prof. Dr. Dede Rosyada M.A in a general stadium on August 8, 2014, university graduates understand how to design learning material. In order to maintain the quality, a further education is needed. It is an integral part of teachers' professional education program, therefore, a new system needs to be managed. The procedures should be flexible that can meet the teachers' needs.

\subsection{Practical Teaching Experience}

Teachers should also master the practical experience related to their subjects. Senior teachers are positioned as professionals that teach teachers. The professionals are not merely academics, but those who have been experienced in teachings. If not, the program is not going to be different from the previous program.[10] 


\subsection{Professional Allowance}

It is used to support teachers' welfare. It is widely known that teachers' welfare in Indonesia is way below the expectation. This situation motivates teachers to have extra jobs, such as doing business. The improvement of teachers' welfare is an improvement of their quality since it avoids them to have extra jobs. Therefore, one of the efforts is that the government provides teachers' with professional allowance. Professional allowance requires moral and academic accountability. The person should meet the requirements and the predetermined standard. In short, the professional allowance is needed to help to emphasize the teachers' competency based on their specified area of study.

\subsection{Supervision}

Supervision is conducted in order to improve teachers' competency. According to Sergiovanni, quoted by Ibrahim Bafadal, there are three functions of supervisions; developing, motivating and controlling. First, the supervision helps teachers to develop their ability to manage the teaching and learning process. Second, the supervision motivates teachers to improve their work quality. Third, the supervision controls the teachers' responsibilities.[11].

\subsection{Collaboration}

In order to produce professional teachers, in terms of academics and pedagogics, it is necessary to have a collaborative approach among the education and non-education faculties.[12]. For example, in order to get professional fiqh teacher, the graduate of Syari'ah Faculty should follow the teachers' professional education program at the Tarbiyah faculty. By having this collaboration, a teacher does not only master his/her subject, but she/he has competencies in teaching what she/he has.

\section{Conclusion}

Teachers' professionalism has been one of the major education problems. The availability of facilities and other supports do not warranty the improvement of education quality. A good education relies on its teachers. The quality of education refers to the government regulation no 19 the year 2005 about the national standard of education. The standard quality refers to the quality of its teachers. It is necessary to improve the quality of teachers by managing a program that helps teachers to be professional. Ensuring that teachers are the graduates of education program, teachers are those who follow teachers' professional education program, the professional allowance, supervision, and collaboration are several possible ways to help to improve the quality of professional teachers in Indonesia.

\section{References}

[1] A. Nata, "Ilmu Pendidikan Islam," Jakarta Kencana, 2010.

[2] A. Nata, Paradigma pendidikan Islam: kapita selekta pendidikan Islam. Gramedia Widiasarana Indonesia bekerjasama dengan IAIN Syarif Hidayatullah, 2001.

[3] M. Saifulloh, Z. Muhibbin, H. H.-J. S. Humaniora, and undefined 2012, "Strategi Peningkatan 
Mutu Pendidikan Di Sekolah,” iptek.its.ac.id.

[4] J. H. Sinamo, 8 Etos Keguruan. Institut Darma Mahardika, 2010.

[5] J. L. Brown, S. M. Jones, M. D. LaRusso, and J. L. Aber, "Improving Classroom Quality: Teacher Influences and Experimental Impacts of the 4Rs Program,” J. Educ. Psychol., vol. 102, no. 1, pp. 153-167, Feb. 2010.

[6] L. Harvey and D. Green, "Defining Quality," Assess. Eval. High. Educ., vol. 18, no. 1, pp. 9-34, Jan. 1993.

[7] Wahono, "Kualitas Pembelajaran Siswa SMK Ditinjau Dari Fasilitas Belajar," J. Ilm. Guru "COPE" No. 01/Tahun XVIII/Mei 2014, no. 01, pp. 1-7, 2016.

[8] R. Rahman, "Modernisasi Pendidikan Islam Awal Abad 20 (Studi Kasus di Sumatera Barat)," Humanus, vol. 14, no. 2, p. 174, Nov. 2015.

[9] I. Helleve, A. Grov Almås, and B. Bjørkelo, "Becoming a professional digital competent teacher," Prof. Dev. Educ., 2019.

[10] R. Rahman, D. F. Kher, and Y. A. Rani, "Pendidikan Islam Bagi Remaja (Upaya Penguatan karakter Dengan Pendekatan Agama," Islam Transform. J. Islam. Stud., vol. 1, no. 2, pp. 95-104, Mar. 2018.

[11] A. Bates and M. Burbank, "Agency in Teacher Supervision and Mentoring," Educ. Fac. Res., Jan. 2019.

[12] A. Honigsfeld and M. G. Dove, "Preparing Teachers for Co-Teaching and Collaboration," in The Handbook of TESOL in K-12, John Wiley \& Sons, Ltd, 2019, pp. 405-421. 